\title{
Effects of dissolved oxygen concentrations on growth, survival and gonadal development of freshwater pearl mussel Lamellidens marginalis
}

\author{
MD. FIDA HASSAN KAFI ${ }^{\mathrm{a}}$, MD. HASIBUL ISLAM ${ }^{\mathrm{a}}$, MD. HELAL UDDIN ${ }^{\mathrm{a}}$, \\ KIZAR AHMED SUMON AND HARUNUR RASHID* \\ Department of Fisheries Management, \\ Bangladesh Agricultural University, Mymensingh 2202, Bangladesh \\ a Equally contribution first authors; 'Corresponding Author: rashid@bau.edu.bd
}

\begin{abstract}
The present study was conducted to evaluate the effects of dissolved oxygen concentrations on growth, survival and gonadal development of freshwater pearl mussel (Lamellidens marginalis). Twenty adult L. marginalis were exposed to each of the five different concentrations of dissolved oxygen (DO) i.e (T0, no aeration), and T1, T2, T3 and T4 with one, two, three and four air stone aerators, respectively in fifteen glass aquaria each containing $10 \mathrm{~L}$ of pond water. DO concentrations were significantly higher in all the treatments compared to the control but there were no significant differences among the treatments. There were significant differences in the growth and survival rates between control and treatments. The relative growth rates (\%) were significantly higher in the highest oxygen concentration (T4) compared to other treatments. The survival rate was zero in control (T0), whereas it was $66.67 \%, 70.00 \%, 71.67 \%$ and $73.33 \%$, respectively for T1, T2, T3 and $\mathrm{T} 4$. On day-30, oocytes in $\mathrm{T} 0$ were found to be smaller in size, with developing acini and no previtellogenic oocytes; whereas in T1, T2, T3 and T4, previtellogenic oocytes and larger acini were evident. On day-60, vitellogenic oocytes along with few under-developed oocytes started to detach from the acini walls, as well as some already started migration to germinal duct on day-90. This indicates that ovaries of all the treatments were ripe and were ready to spawn between day-60 and -90 . On day-30, secondary spermatocytes were observed in testicular acini in case of T0, whereas more developed and dense spermatids were evident in T1, T2, T3 and T4. These results indicate that testes were in late development stages in T0, whereas they were ripe in all the treatments. The current findings indicate that hypoxia slows down growth, reduces survival rate and retards development of reproductive organs in L. marginalis.
\end{abstract}

Keywords: Freshwater pearl mussel, Lamellidens marginalis, dissolved oxygen, hypoxia, climate change

\section{Introduction}

Climate change is affecting aquatic systems by warming water temperatures, changing stream flow patterns and triggering storm events (Poff et al. 2002). It also affects the distribution and phenology of species and the productivity of aquatic ecosystems (Parmesan 2006). Global climate change is warming the water temperature thus create stressful conditions for aquatic organisms (Sharma et al. 2007). At current emission rates temperatures could increase by $2^{\circ} \mathrm{C}$, which the United Nations Intergovernmental Panel on Climate Change (IPCC) designated as the upper limit to avoid dangerous levels by 2036 (Mann 2016). Rising $\mathrm{CO}_{2}$ levels in the atmosphere have concurrently led to higher water temperatures that have, in turn, depressed dissolved oxygen levels (Keeling et al. 2010, Doney et al. 2012). Low levels of dissolved oxygen (DO) reduce the survival, growth and physiological activities of aquatic organisms. Low DO levels also increase respiration rates evidencing a compensatory physiological response to hypoxia. The combination of low DO and low pH often interacted antagonistically to yield growth rates higher than would be predicted from either individual stressor, potentially

https://doi.org/10.52168/bjf.2021.33.12 


\section{EFFECTS OF DISSOLVED OXYGEN CONCENTRATIONS ON GROWTH, SURVIVAL AND GONADAL DEVELOPMENT OF LAMELLIDENS MARGINALIS}

suggesting that some anaerobic metabolic pathways may function optimally under hypercapnia (Stevens and Gobler 2018). The changes of free $\mathrm{CO}_{2}, \mathrm{pH}$, and DO in carbonate chemistry can inhibit the ability of calcifying organisms to produce an exoskeleton and can have other cascading effects on early life stage bivalves, including slowed growth and mortality (Talmage and Gobler 2010, Waldbusser et al. 2013).

Filter feeding bivalves are an essential component of aquatic ecosystems and are often considered ecosystem engineers for their role to mitigate eutrophication (Officer et al. 1982), improvement of light availability (Wall et al. 2008), recycling nutrients and organic matter (Dame 1996, Carroll et al. 2008) and overall it plays an important role to make aquatic ecosystems less susceptible to algal blooms (Cerrato et al. 2004, Gobler et al. 2005). The microbial decay of enhanced productivity increases community respiration and can create hypoxia (Diaz and Rosenberg 2008), a condition that is stressful for aquatic organisms that may live within or near oxygen-depleted regions and has become more common since the mid-20th century (Diaz and Rosenberg 2008, Rabalais et al. 2010). Sessile organisms, such as bivalves, which have limited mobility, are particularly vulnerable to hypoxic events (Diaz and Rosenberg 1995, Levin et al. 2009). Rising water temperatures can compound the intensity of hypoxia by both lowering gas solubility and increasing stratification, thereby reducing mixing and ventilation throughout the water column (Keeling et al. 2010, Doney et al. 2012). Hypoxia is such a stress created when dissolved oxygen level is below $2 \mathrm{mg} / \mathrm{L}$ (Long et al. 2008). Bivalve mollusk is no longer able to maintain its normal aerobic metabolism at oxygen concentration below $2 \mathrm{mg} / \mathrm{L}$ (Tang and Riisgård 2018). Hypoxic condition decreases the abundance, biomass and the diversity of sessile benthic community (Rosenberg 1977, Gaston 1985, Dauer et al. 1992, Diaz et al. 1992, Llansó 1992, Powers et al. 2005).

Mollusks constitute the second largest group next to arthropods (Khalua et al. 2014). The class Bivalvia holds the record within the animal kingdom for the greatest number of species, which attain ages in excess of 150 years (Abele et al. 2008). Among 85,000 extant species of mollusks freshwater pearl mussel (Lamellidens marginalis) is a common freshwater bivalve, widely distributed and abundantly found in the freshwater ponds, lakes, rivers and other water bodies of Bangladesh, Nepal and India (Ramakrishna and Dey 2007, Rao 1989). It is an important pearl producing bivalve and is commonly known as Pearl Mussel and has an increasing demand in pearl producing countries (Seed 1968). It is an economically, nutritionally and medicinally important freshwater bivalve and is commonly named as 'jhinuk' in rural and urban areas of Bangladesh (Alam 1994). The objectives of the present research work were to determine the effects of hypoxic and normoxic conditions on the growth, survival and gonadal development of freshwater pearl mussel.

\section{Materials and Methods}

Sample collection: Adult freshwater pearl mussels Lamellidens marginalis were collected from the ponds of Fisheries Field complex, Faculty of Fisheries, Bangladesh Agricultural University (BAU), Mymensingh by hand picking. Around 300 individuals (almost similar in size) were collected in a plastic bucket and acclimatized in laboratory condition for 15 days prior to start the experiment. 
Experimental setup: In the present study, each of the 20 L. marginalis was exposed to 15 glass aquaria $\left(46 \times 31 \times 25 \mathrm{~cm}^{3}\right)$ containing $10 \mathrm{~L}$ of pond water with three replications. The treatments have been designated as T1 (one air stone), T2 (two air stone), T3 (three air stone) and T4 (four air stone). Phytoplankton was collected from adjacent ponds of Field Laboratory (BAU) by using plankton net in order to feed $L$. marginalis twice in a day. Water quality parameters (DO, $\mathrm{pH}$ and temperature) were measured at fifteen days interval by using multi meter (HQ4200 Portable Multi-Meter). Bivalves were sampled on days $-30,-60$ and -90 in order to study the growth and to collect gonad tissue for histopathological study.

Growth and survival study: Length was measured from maximum antero-posterior distance; width was measured from top hinge joint to lower shell edge distance using measuring scale. Relative growth rate (RGR, \%) was calculated using the following formula: [(W2-W1/W1) $\times$ 100]; where W2 and W1 is the final and initial weight, respectively. To determine the survival of mussels, every individual of each aquarium was monitored every day. Any mussel having its valve open or having the smell of decomposition was treated as a dead one. The survival rate of each aquarium in each sampling was expressed in percentage and was calculated using the following formula: $[(S=n / N) \times 100]$; Where, $S$ is the survival rate $(\%), n$ is the number survived; $\mathrm{N}$ is the initial number stocked.

Histological procedure: The similar histopathological procedures were followed as described in Sumon et al. (2019). Briefly, the preserved fixated gonadal tissues, three from each group including control were dehydrated by passing through graded alcohol series and cleared by chloroform and embedded into paraffin. Sectioning was done using a microtome. The sampled sections were stained with Haematoxylene-Eosin (HE) stains and mounted with DPX. Finally, the sample sections were observed under a digital microscope (Olympus CX 41) to examine the gonadal development.

Statistical analysis: Values are expressed as means \pm standard deviation (SD). Data were analyzed by a one-way analysis of variance (ANOVA) followed by Tukey's post hoc test to assess statistically significant differences among different treatments. Statistical significance was set at $p<0.05$. Statistical analyses were performed using PASW Statistics 18.0 software (IBM SPSS Statistics, IBM, Chicago, USA).

\section{Results}

Water quality parameters: Dissolved oxygen $(\mathrm{mg} / \mathrm{L})$ values were found to be hypoxic condition in control group (T0) on day-30 from starting the experiment and rest of the days it was in noromoxic condition. Whereas in the treatments groups (T1, T2, T3, and T4), DO concentrations were normoxic conditions throughout the experimental period (Table I). There was a significant difference between the control group and the treatments groups but no noticeable differences were observed among the treatments. In contrast, the values of $\mathrm{pH}$ and temperature were almost unchanged throughout the study period (Table I).

Growth and survival of L. marginalis: Relative growth rate (RGR \%) was calculated in terms of length, weight and width during the experimental period. No data (ND) were available as $100 \%$ mortality recorded in control group (T0) on day-30 due to hypoxia. The RGR in terms of 


\section{EFFECTS OF DISSOLVED OXYGEN CONCENTRATIONS ON GROWTH, SURVIVAL AND GONADAL DEVELOPMENT OF LAMELLIDENS MARGINALIS}

length, weight and width were significantly higher in $\mathrm{T} 4$ compared to $\mathrm{T} 1, \mathrm{~T} 2$ and $\mathrm{T} 3$ throughout the experiment (Table II). Average survival rate (\%) was also recorded during the experiment. The survival rate was zero in control (T0), whereas it was $66.67 \%, 70.00 \%, 71.67 \%$ and $73.33 \%$ for $\mathrm{T} 1, \mathrm{~T} 2, \mathrm{~T} 3$ and $\mathrm{T} 4$, respectively.

Table I. Water quality parameters (mean \pm SD) during the experimental period

\begin{tabular}{|c|c|c|c|c|c|c|c|c|}
\hline \multirow[t]{2}{*}{ Parameters } & \multirow[t]{2}{*}{ Treatments } & \multicolumn{7}{|c|}{ Sampling Days } \\
\hline & & Day-0 & Day-15 & Day-30 & Day-45 & Day-60 & Day-75 & Day-90 \\
\hline \multirow[t]{5}{*}{ DO $(\mathrm{mg} / \mathrm{L})$} & T0 & $5.11 \pm 0.05^{\mathrm{a}}$ & $0.82 \pm 0.05^{\mathrm{a}}$ & $1.61 \pm 0.06^{\mathrm{a}}$ & $3.31 \pm 0.07^{\mathrm{a}}$ & $5.34 \pm 0.04^{\mathrm{a}}$ & $5.42 \pm 0.06^{\mathrm{a}}$ & $5.44 \pm 0.06^{\mathrm{a}}$ \\
\hline & $\mathrm{T} 1$ & $7.55 \pm 0.16^{\mathrm{b}}$ & $7.31 \pm 0.37^{\mathrm{b}}$ & $7.30 \pm 0.26^{b}$ & $7.12 \pm 0.19^{b}$ & $7.01 \pm 0.40^{b}$ & $7.25 \pm 0.18^{\mathrm{b}}$ & $7.22 \pm 0.12^{\mathrm{b}}$ \\
\hline & $\mathrm{T} 2$ & $7.86 \pm 0.03^{\mathrm{c}}$ & $7.86 \pm 0.15^{\mathrm{c}}$ & $7.81 \pm 0.05^{\mathrm{c}}$ & $7.72 \pm 0.05^{\mathrm{c}}$ & $7.57 \pm 0.03^{\mathrm{c}}$ & $7.58 \pm 0.02^{\mathrm{c}}$ & $7.62 \pm 0.03^{\mathrm{c}}$ \\
\hline & T3 & $7.88 \pm 0.01^{\mathrm{c}}$ & $7.90 \pm 0.05^{\mathrm{c}}$ & $7.93 \pm 0.02^{\mathrm{c}}$ & $7.81 \pm 0.02^{\mathrm{c}}$ & $7.46 \pm 0.24^{\mathrm{c}}$ & $7.75 \pm 0.04^{\mathrm{c}}$ & $7.76 \pm 0.06^{\mathrm{c}}$ \\
\hline & $\mathrm{T} 4$ & $7.87 \pm 0.02^{\mathrm{c}}$ & $7.69 \pm 0.06^{\mathrm{c}}$ & $7.76 \pm 0.08^{\mathrm{c}}$ & $7.85 \pm 0.02^{\mathrm{c}}$ & $7.37 \pm 0.28^{\mathrm{c}}$ & $7.64 \pm 0.25^{\mathrm{c}}$ & $7.71 \pm 0.13^{\mathrm{c}}$ \\
\hline \multirow[t]{5}{*}{$\mathrm{p}^{\mathrm{H}}$} & T0 & $8.39 \pm 0.02$ & $7.54 \pm 0.04$ & $7.51 \pm 0.02$ & $7.45 \pm 0.08$ & $7.36 \pm 0.03$ & $7.28 \pm 0.06$ & $7.24 \pm 0.04$ \\
\hline & $\mathrm{T} 1$ & $8.46 \pm 0.07$ & $8.02 \pm 0.13$ & $8.02 \pm 0.13$ & $8.08 \pm 0.27$ & $8.16 \pm 0.20$ & $8.13 \pm 0.30$ & $8.00 \pm 0.30$ \\
\hline & $\mathrm{T} 2$ & $8.48 \pm 0.02$ & $8.07 \pm 0.08$ & $8.13 \pm 0.06$ & $8.35 \pm 0.08$ & $8.39 \pm 0.08$ & $8.39 \pm 0.09$ & $8.30 \pm 0.10$ \\
\hline & T3 & $8.40 \pm 0.02$ & $8.12 \pm 0.03$ & $8.08 \pm 0.02$ & $8.42 \pm 0.04$ & $8.40 \pm 0.02$ & $8.41 \pm 0.10$ & $8.38 \pm 0.04$ \\
\hline & $\mathrm{T} 4$ & $8.31 \pm 0.05$ & $8.07 \pm 0.04$ & $8.02 \pm 0.04$ & $8.37 \pm 0.06$ & $8.32 \pm 0.03$ & $8.36 \pm 0.17$ & $8.37 \pm 0.13$ \\
\hline \multirow{5}{*}{$\begin{array}{l}\text { Temperature } \\
\left({ }^{0} \mathrm{C}\right)\end{array}$} & $\mathrm{T} 0$ & $29.97 \pm .15$ & $26.67 \pm 0.06$ & $29.07 \pm 0.06$ & $29.67 \pm 0.06$ & $29.37 \pm 0.06$ & $29.93 \pm 0.06$ & $30.00 \pm 0.10$ \\
\hline & $\mathrm{T} 1$ & $29.93 \pm .15$ & $26.53 \pm 0.06$ & $28.50 \pm 0.17$ & $29.80 \pm 0.00$ & $29.00 \pm 0.10$ & $30.07 \pm 0.06$ & $29.87 \pm 0.06$ \\
\hline & $\mathrm{T} 2$ & $29.73 \pm .06$ & $26.57 \pm 0.06$ & $28.40 \pm 0.10$ & $29.87 \pm 0.06$ & $28.97 \pm 0.06$ & $29.93 \pm 0.06$ & $29.90 \pm 0.10$ \\
\hline & T3 & $29.63 \pm .06$ & $26.53 \pm 0.06$ & $28.30 \pm 0.00$ & $29.87 \pm 0.06$ & $28.87 \pm 0.35$ & $30.10 \pm 0.00$ & $30.00 \pm 0.10$ \\
\hline & $\mathrm{T} 4$ & $29.57 \pm .06$ & $26.57 \pm 0.06$ & $28.50 \pm 0.10$ & $29.87 \pm 0.06$ & $28.93 \pm 0.06$ & $30.03 \pm 0.12$ & $29.93 \pm 0.06$ \\
\hline
\end{tabular}

Values with different alphabetical superscripts in a row differ significantly $(\mathrm{P}<0.05)$ among different treatments.

All values were expressed as mean $\pm \mathrm{SD}$.

Table II. Relative growth rate measurement (mean \pm SD) during the experimental period

\begin{tabular}{|c|c|c|c|c|c|}
\hline \multirow[t]{2}{*}{ Parameters } & \multirow[t]{2}{*}{ Treatments } & \multicolumn{4}{|c|}{ Sampling Days } \\
\hline & & Day-0 & Day-30 & Day-60 & Day-90 \\
\hline \multirow[t]{5}{*}{ Length $(\mathrm{cm})$} & $\mathrm{T} 0$ & $7.26 \pm 0.61^{c}$ & ND & ND & ND \\
\hline & $\mathrm{T} 1$ & $7.19 \pm 0.5^{\mathrm{c}}$ & $7.35 \pm 0.35^{b}$ & $7.53 \pm 0.65^{c}$ & $7.68 \pm 0.41^{\mathrm{b}}$ \\
\hline & $\mathrm{T} 2$ & $6.85 \pm 0.84^{\mathrm{a}}$ & $6.99 \pm 0.84^{\mathrm{a}}$ & $7.12 \pm 0.31^{\mathrm{a}}$ & $7.26 \pm 0.44^{\mathrm{a}}$ \\
\hline & $\mathrm{T} 3$ & $6.97 \pm 0.55^{\mathrm{a}}$ & $7.33 \pm 0.31^{b}$ & $7.47 \pm 0.36^{\mathrm{b}}$ & $7.67 \pm 0.65^{b}$ \\
\hline & $\mathrm{T} 4$ & $7.12 \pm 0.61^{b}$ & $7.40 \pm 0.45^{\mathrm{c}}$ & $7.55 \pm 0.69^{c}$ & $7.76 \pm 0.40^{c}$ \\
\hline \multirow[t]{5}{*}{ Width (cm) } & $\mathrm{T} 0$ & $3.65 \pm 0.40^{b}$ & ND & ND & ND \\
\hline & $\mathrm{T} 1$ & $3.64 \pm 0.2^{\mathrm{b}}$ & $3.69 \pm 0.26^{\mathrm{a}}$ & $3.74 \pm 0.42^{\mathrm{b}}$ & $3.81 \pm 0.32^{\mathrm{b}}$ \\
\hline & $\mathrm{T} 2$ & $3.59 \pm 0.39^{\mathrm{a}}$ & $3.66 \pm 0.21^{\mathrm{a}}$ & $3.71 \pm 8.1^{\mathrm{b}}$ & $3.77 \pm 0.17^{\mathrm{a}}$ \\
\hline & $\mathrm{T} 3$ & $3.57 \pm 0.32^{\mathrm{a}}$ & $3.63 \pm 0.54^{\mathrm{a}}$ & $3.69 \pm 7.63^{\mathrm{a}}$ & $3.77 \pm 0.32^{\mathrm{a}}$ \\
\hline & $\mathrm{T} 4$ & $3.67 \pm 0.39^{b}$ & $3.75 \pm 0.22^{b}$ & $3.82 \pm 0.45^{\mathrm{c}}$ & $3.88 \pm 0.22^{\mathrm{b}}$ \\
\hline \multirow[t]{5}{*}{ Weight (g) } & $\mathrm{T} 0$ & $37.18 \pm 7.20^{\mathrm{c}}$ & ND & ND & ND \\
\hline & $\mathrm{T} 1$ & $32.35 \pm 8.2^{\mathrm{a}}$ & $33.22 \pm 8.2^{\mathrm{a}}$ & $34.36 \pm 8.7^{\mathrm{a}}$ & $35.82 \pm 6.59^{\mathrm{a}}$ \\
\hline & $\mathrm{T} 2$ & $32.12 \pm 7.31^{\mathrm{a}}$ & $33.16 \pm 7.36^{\mathrm{a}}$ & $34.21 \pm 0.62^{\mathrm{a}}$ & $35.63 \pm 8.30^{\mathrm{a}}$ \\
\hline & $\mathrm{T} 3$ & $32.22 \pm 7.51^{\mathrm{a}}$ & $33.36 \pm 7.15^{\mathrm{a}}$ & $34.55 \pm 0.63^{\mathrm{a}}$ & $35.87 \pm 7.57^{\mathrm{a}}$ \\
\hline & $\mathrm{T} 4$ & $34.36 \pm 7.65^{\mathrm{b}}$ & $36.13 \pm 7.36^{\mathrm{b}}$ & $37.54 \pm 8.20^{\mathrm{b}}$ & $38.33 \pm 7.39^{b}$ \\
\hline
\end{tabular}

Values with different alphabetical superscripts in a row differ significantly $(\mathrm{P}<0.05)$ among different treatments.

All values were expressed as mean $\pm \mathrm{SD}$. $\mathrm{ND}=$ no data

Histological observations of reproductive organs of $L$. marginalis: On day-30, the ovaries extracted from the control group (T0) revealed that oocytes are developing in acini, no 
previtellogenic oocytes were found whereas larger acini and previtellogenic oocytes were found in T1, T2, T3 and T4 compared to control (Fig. 1).

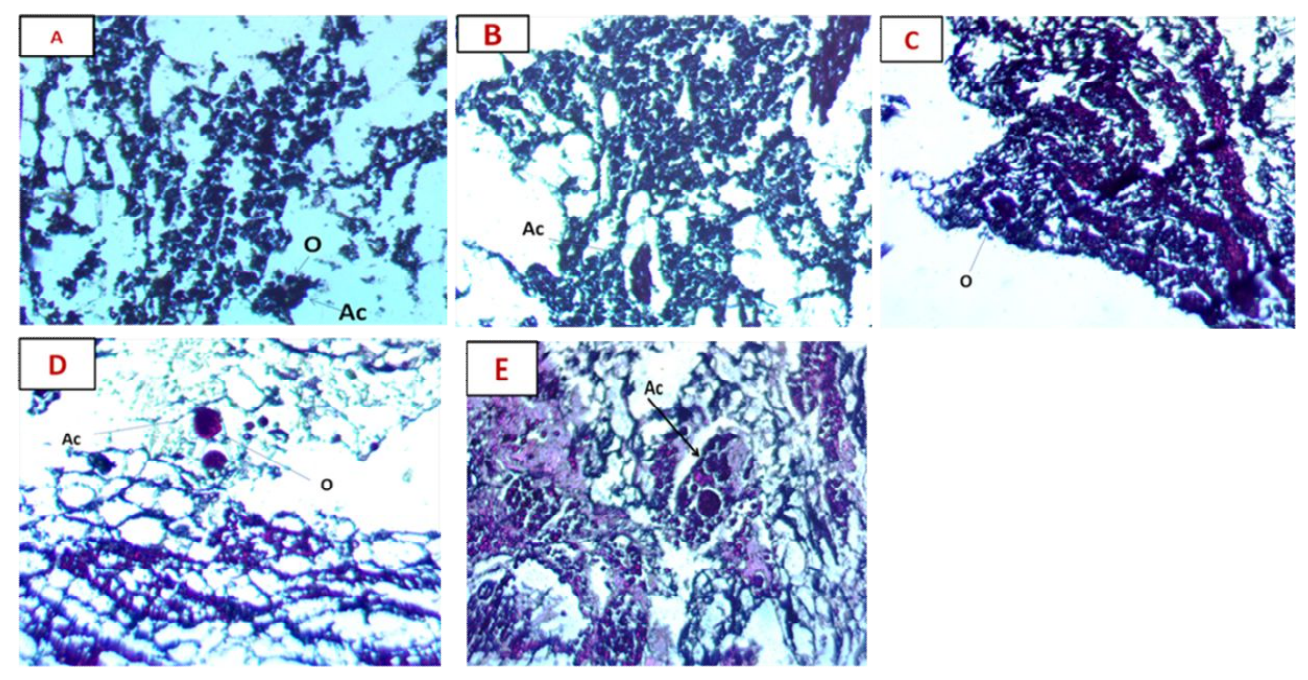

Fig. 1. Histo-snaps (10X) of L. marginalis ovary sampled on day 30; (A) T0, (B) T1, (C) T2, (D) T3 and (E) T4; Ac - Acini, O - Oocyte

On day -60 , histological observation showed that acini were larger in size; oval shaped and different types of oocytes were found. Both previtellogenic and vitellogenic oocytes were abundantly observed in T1, T2, T3 and T4 (Fig. 2).

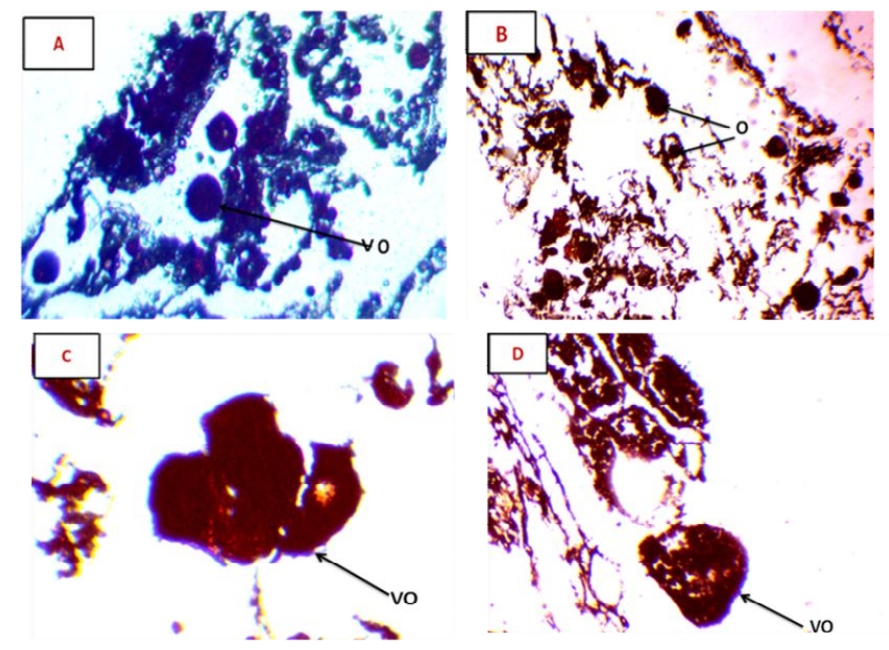

Fig. 2. Histo-snaps (10X) of $L$. marginalis ovary sampled on day 60; (A) T1, (B) T2, (C) T3 and (D) T4; VO - Vitellogenic Oocyte, O - Oocyte. 


\section{EFFECTS OF DISSOLVED OXYGEN CONCENTRATIONS ON GROWTH, SURVIVAL AND GONADAL DEVELOPMENT OF LAMELLIDENS MARGINALIS}

Similarly on day 90 , histological snaps of $L$. marginalis ovaries revealed that oocytes were larger in size; oocytes started to release from the acini in T1 and T2, T3 but still attached in acini wall (Fig. 3- A; B; C). Oocytes were released from the acini and were dispersed in T4 (Fig. 3-D).

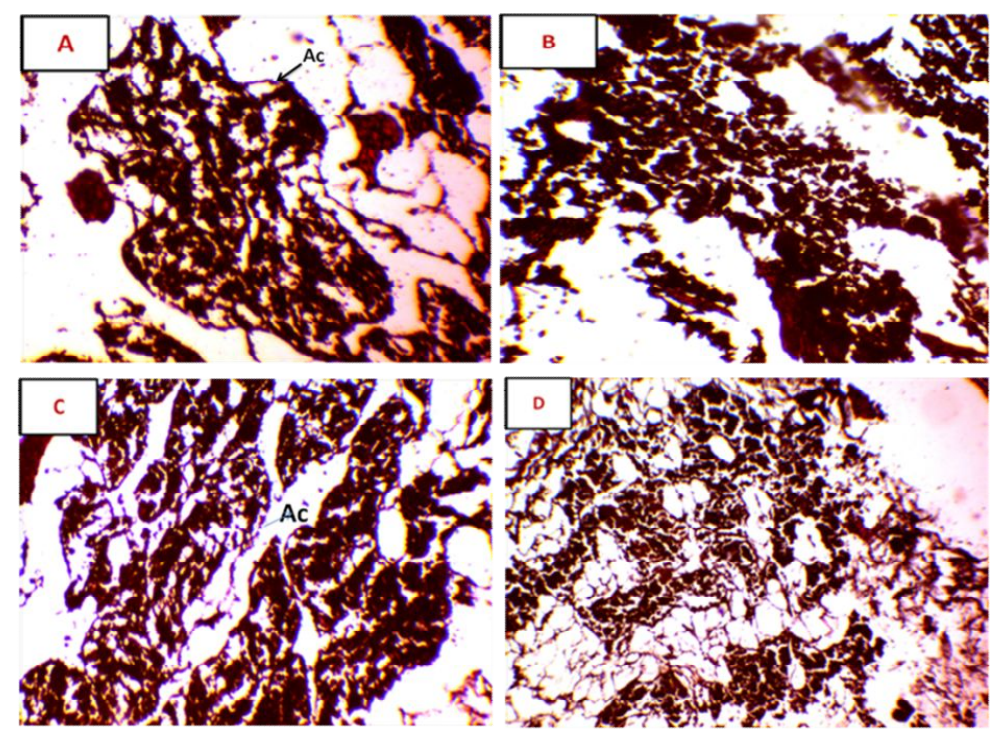

Fig. 3. Histo-snaps (10X) of L. marginalis ovary sampled on day 90; (A) T0, (B) T1, (C) T2, (D) T3 and (E) T4; Ac - Acini, O - Oocyte

Histological observations of $L$. marginalis testis at day-30 revealed that spermatocytes were developing in acini at T0 (Fig. 4-A). Through spermatogenesis spermatocytes were developed in spermatids, spermatogonia were found in the acini wall in T1, T2, T3 and T4 (Figure 4-B, C, $\mathrm{D}, \mathrm{E})$.
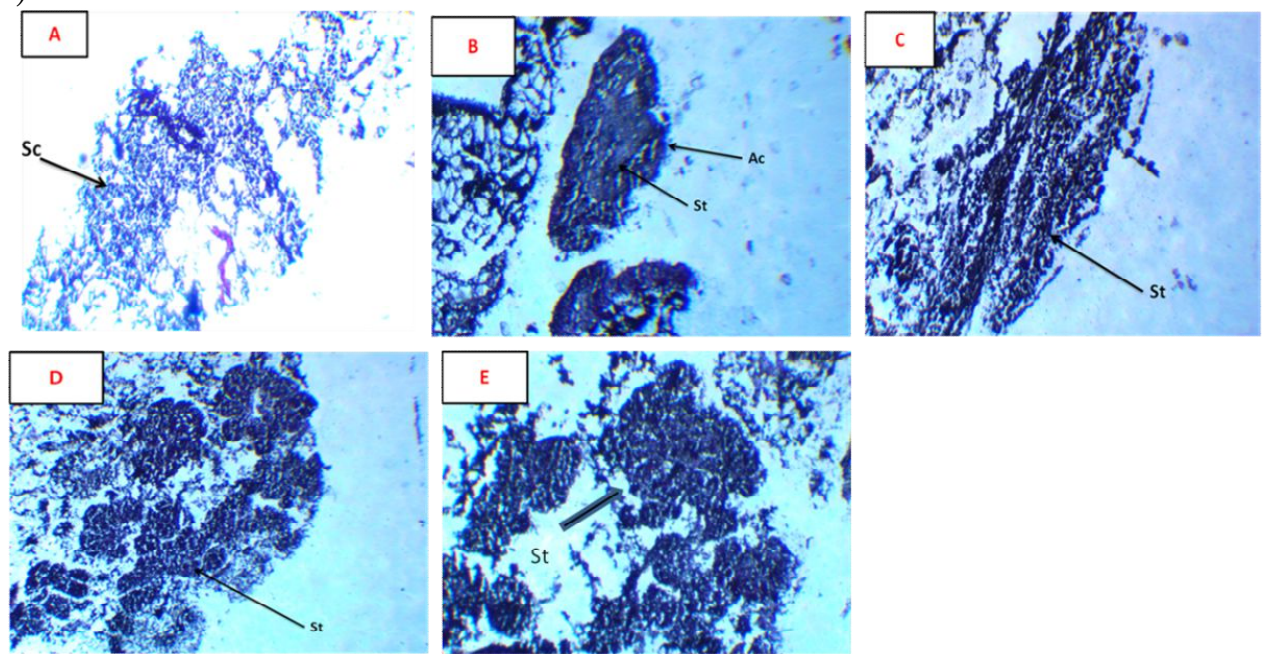

Fig. 4. Histo-snaps (10X) of L. marginalis testis sampled on day 30; (A) T0, (B) T1, (C) T2, (D) T3 and (E) T4; Ac - acini, Sc - spermatocytes, St - spermatid 


\section{Discussion}

Stress is a condition which is capable of retarding growth and important physiological functions like growth and reproduction of animals by interrupting homeostasis (Hamid et al. 2013). DO is one of the most crucial parameters which play an important role to make an animal living in comfortable or stressful conditions. Sessile organisms, such as bivalves, are particularly vulnerable to low DO events (Diaz and Rosenberg 1995, Levin et al. 2009). Due to climate change effects, fluctuations in water temperatures are frequent, capable of altering DO levels in natural waters (Keeling et al. 2010, Doney et al. 2012). The current research findings revealed that for control group (T0), DO concentrations were $<2 \mathrm{mg} / \mathrm{L}$ for first 30 days indicating hypoxia, followed by normoxia from day-45 onwards. In case of T1, T2, T3 and T4, DO concentrations were $>2 \mathrm{mg} / \mathrm{L}$ throughout the experiment indicating normoxia. On day-15, -30 , $-45,-60,-75$ and $-90, \mathrm{DO}$ concentrations in the treatments (T1, T2, T3 and T4) were significantly higher than control (T0); but there were no significant differences among the treatments (T1, T2, T3 and T4). These results indicate that number of air stones in T1, T2, T3 and T4 did not change DO levels significantly. During the experiment, water temperature ranged from $26.53 \pm 0.06^{\circ} \mathrm{C}$ to $30.10 \pm 0.00^{\circ} \mathrm{C}$. In the present study, survival rate was recorded $0 \%$ in control (T0); whereas survival rates were documented $66.67 \%, 70.00 \%, 71.67 \%$ and $73.33 \%$ for $\mathrm{T} 1, \mathrm{~T} 2, \mathrm{~T} 3$ and $\mathrm{T} 4$, respectively. These results indicate that $100 \%$ bivalve mortality occurred in control where DO concentration was hypoxic $(0.82-1.61 \mathrm{mg} / \mathrm{L})$. Long et al. (2008) reported that the lethal concentration for $50 \%$ of the bivalve $M$. balthica population (LC50) was $1.7 \mathrm{mg} / \mathrm{L}$ which is supportive to our findings. Similarly, Borsuk et al. (2002) modeled the survival of $M$. balthica using a compilation of literature values and estimated a 21-day LC50 of $1.5 \mathrm{mg} / \mathrm{L}$. In contrary to our findings, Cheung et al. (2008) demonstrated high tolerance of a marine scavenging gastropod Nassarius festivus to prolong hypoxia with a very low mortality $(15 \%$ at $1.5 \mathrm{mg} / \mathrm{L})$. In the present study, the growth rates, in terms of length and weight gain, were significantly higher in T4 compared to other treatments. On the other hand, no significant differences were observed in width gain. Cheung et al. (2008) reported that $N$. festivus exposed to 6.0 (normoxia), 3.0 (normoxia) and 1.5 (hypoxia) $\mathrm{mg} / \mathrm{L}$ of DO for 8 weeks gained $12 \%, 6 \%$ and 5\% shell length, respectively. Three North Atlantic bivalves - eastern oysters (Crassostrea virginica), blue mussels (Mytilus edulis) and hard clams (Mercenaria mercenaria) - exposed to hypoxic conditions for one month showed reduction in the survival, shell growth, and/or tissue weight of each bivalve (Stevens et al. 2018) which is similar to the present research findings. The characteristics of female gonad development are the presence of acinus, oogonia and small previtellogenic oocytes attached to the acini wall and numerous nutritive granules (Srakaew et al. 2010). On day-30, in control (T0) we observed smaller oocytes attached with acini wall and no previtellogenic oocytes were found in the acini; whereas oocytes were larger in the acini and few previtellogenic oocytes were formed in the previtellogenic space of all the four treatments (T1, T2, T3 and T4). Ovaries were more developed in all the four treatments compared to control, indicating the fact that low DO concentration of water retards the development of oocytes in L. marginalis. On day-60, oocytes were larger in size, both previtellogenic and vitellogenic oocytes were evident and ripe oocytes were attached to the acini wall in all the treatments compared to control. On day-90, most of the oocytes in the treatments started to migrate from the acini to the germinal duct indicated that oocytes were ready to spawn; later, oocytes were found to detach from the acini wall and dispersed. Niogee et al. (2019) reported that peak spawning season of L. marginalis was September and October. In this study, we found 


\section{EFFECTS OF DISSOLVED OXYGEN CONCENTRATIONS ON GROWTH, SURVIVAL AND GONADAL DEVELOPMENT OF LAMELLIDENS MARGINALIS}

oocytes ready to spawn in October in all the four treatments exposed to normoxia, whereas T0 (hypoxia) experienced slower gonadal development. Our histological observations revealed that the testes were composed of numerous structural units of acini with connective tissues interspersed among them. Secondary spermatocytes were found to dominate the T0 acini, whereas in all the treatments (T1, T2, T3 and T4), acini were dominated by spermatids.. Therefore, normoxia enhanced gonadal development (ripe acini) in all the four treatments and hypoxia retarded (late development stage) the same in T0. Srakaew et al. (2010) reported that the development of ovaries began later than testes but took shorter time to reach maturity. In day-30 samples, we observed ovaries at late development stage, whereas testes became ripe, similar to the findings of Srakaew et al. (2010). Cheung et al. (2008) reported that $N$. festivus exposed to hypoxia reduced $70 \%$ reproductive capacity compared to normoxia. Female Baltic clam Macoma balthica exposed to sublethal hypoxic condition produced $40 \%$ fewer eggs than those in normoxic condition (Long et al. 2014) which is also supportive to our findings.

The present research concludes that low DO is stressful to freshwater pearl mussel L. marginalis causing slow growth, reduced survival rate and retarded gonadal development, and capable of bringing changes in maturity and reproduction cycles.

Acknowledgement: This work was funded by BAURES, Bangladesh Agricultural University, Mymensingh, Bangladesh (Project no. 2018/652/BAU).

\section{Literature Cited}

Abele, D., J. Strahl, T. Brey and E. Philipp, 2008. Imperceptible senescence: ageing in the ocean quahog Arctica islandica. Free Rad. Res., 42: 474-480.

Alam, A.B.M.T., 1994. Mukta Chash: Somridhir Nutan Diganta. Krishi Kotha, Krishi Kotha Service, Dhaka 54 (8): 254-256.

Borsuk, M.E., S.P. Powersand C.H. Peterson, 2002. A survival model of the effects of bottom-water hypoxia on the population density of an estuarine clam (Macoma balthica). Can. J. Fish. Aquat. Sci., 59: $1266-1274$.

Carroll, J., C.J. Gobler and B.J. Peterson, 2008. Resource-restricted growth of eelgrass in New York estuaries: light limitation, and alleviation of nutrient stress by hard clams. Mar. Ecol. Prog. Ser., 369: 51-62.

Cerrato, R.M., D.A. Caron, D.J. Lonsdale, J.M. Rose and R.A. Schaffner, 2004. Effect of the northern quahog Mercenaria mercenaria on the development of blooms of the brown tide alga Aureococcus anophagefferens. Mar. Ecol. Prog. Ser., 281: 93-108.

Cheung, S.G., H.Y. Chan, C.C. Liu and P.K.S. Shin, 2008. Effect of prolonged hypoxia on food consumption, respiration, growth and reproduction in marine scavenging gastropod Nassarius festivus. Mar. Poll. Bull., 57: 280-286.

Dame, R.F. 1996. Ecology of marine bivalves: an ecosystem approach. CRC Press, New York.

Dauer, D.M., A.J. Rodi and J.A. Ranasinghe, 1992. Effects of low dissolved oxygen events on the macrobenthos of the lower Chesapeake Bay. Estuaries., 15: 348-391.

Diaz, R.J. and R. Rosenberg, 1995 Marine benthic hypoxia: a review of its ecological effects and the behavioural responses of benthic macrofauna. Oceanograp. Mar. Biol. Ann. Rev., 33: 245-303.

Diaz, R.J. and R. Rosenberg, 2008. Spreading dead zones and consequences for marine ecosystems. Science, 321: 926-929.

Diaz, R.J., R.J. Neubauer, L.C. Schaffner, L. Pihl and S.P. Baden, 1992. Continuous monitoring of dissolved oxygen in an estuary experiencing periodic hypoxia and the effect of hypoxia on macrobenthos and fish. Sci.. Total Envron., 1055-1068. 
Doney, S.C., M. Ruckelshaus, J.E. Duffy and J.P. Barry, 2012. Climate change impacts on marine ecosystems. Annu. Rev. Mar. Sci., 4: 11-37.

Gaston, G.R., 1985. Effects of hypoxia on macrobenthos of the inner shelf off Cameron, Louisiana. Estuar. Coast. Shelf. Sci., 20: 603-613.

Gobler, C.J., D.J. Lonsdale and G.L. Boyer, 2005. A review of the causes, effects, and potential management of harmful brown tide blooms caused by Aureococcus anophagefferens (Hargraves et Sieburth). Estuaries, 28: 726-749.

Hamid, S.A., F.M. Ahmed, I.A. Mohammed and S.M. Ali, 2013. Physical and chemical characteristics of blood of two fish species (Oreochromis niloticus and Clarias lazera). World's Vet. J., 3: 17-20.

Keeling, R.F., A. Körtzinger and N. Gruber, 2010. Ocean deoxygenation in a warming world. Annu. Rev. Mar. Sci., 2: 199-229.

Khalua, R. K., S. Tripathy, B. Paul and D. Bairy, 2014. Seasonal Variation of Carbohydrate, Protein and Lipid of Common Freshwater Edible Gastropod (Bellamya bengalensis) of Medinipur District, West Bengal. Res. J. Biol., 2: 49 - 52.

Levin, L.A., W. Ekau, A.J. Gooday and F. Jorissen,2009. Effects of natural and human-induced hypoxia on coastal benthos. Biogeoscience., 6: 2063-2098.

Llansó, R.J., 1992. Effects of hypoxia on estuarine benthos: The lower Rappahannock River (Chesapeake Bay), a Case Study. Estuar. Coast. Shelf. Sci., 359: 491-515.

Long, W.C., B.J. Brylawski and R.D. Seitz, 2008. Behavioral effects of low dissolved oxygen on the bivalve Macoma balthica. J. Exp. Mar. Biol. Ecol., 359: 34-39.

Long, W.C., R.D. Seitz, B.J. Brylawski and R.N. Lipcius, 2014. Individual, population, and ecosystem effects of hypoxia on a dominant benthic bivalve in Chesapeake Bay. Ecol. Monogr. 84(2): 303-327.

Mann, M.E., 2016. Earth will cross the climate danger threshold by 2036. Sci. Am. J., 10: 106-165.

Niogee, S.R., K.F. Tonni, A.C. Barman, M.B. Tanu, S. Sku and M.J. Uddin, 2019. Ovarian Cycle of Freshwater Pearl Mussel, Lamellidens marginalis (Lamarck, 1819) Collected from a Culture Pond in Bangladesh. Asian. Fish. Sci., 32: 117-123.

Officer, CB, T.J. Smayda and R. Mann, 1982. Benthic filter feeding: a natural eutrophication control. Mar. Ecol. Prog. Ser., 9: 203-210.

Parmesan, C., 2006. Ecological and evolutionary responses to recent climate change. Annu. Rev. Ecol. Evol. Syst., 37: 637-669.

Poff, N.L., M.M. Brinson and J.W. Day, 2002. Aquatic ecosystems \& global climate change: potential impacts on inland freshwater and coastal wetland ecosystems in the United States. Pew Center on Global Climate Change, Arlington, Virginia.

Powers, S.P., C.H. Peterson, R.R. Christian, E. Sullivan, M.J. Powers, M.J. Bishop and C.P. Buzzelli, 2005. Effects of eutrophication on bottom habitat and prey resources of demersal fishes. Mar. Ecol. Prog. Ser., 302: 233-243.

Rabalais, N.N., R.J. Diaz, L.A. Levin, R.E. Turner, D. Gilbert and J. Zhang, 2010. Dynamics and distribution of natural and human-caused hypoxia. Biogeoscience., 7: 585-619.

Ramakrishna and A. Dey, 2007. Handbook on Indian freshwater Molluscs. Zoological Survey of India.

Rao, S., 1989. Handbook Freshwater Molluscs of India. 289p.

Rosenberg, R., 1977. Benthic macrofaunal dynamics, production, and dispersion in an oxygen-deficient estuary of west Sweden. J. Exp. Mar. Biol. and Ecol., 26: 107-133.

Seed, R., 1968. Factors influencing shell shape in Mytilus edulis L. J. Mar. Biol. Assoc. UK, 48: 561584.

Sharma, S., D.A. Jackson, C.K. Minns and B.J. Shuter, 2007. Will northern fish populations be in hot water because of climate change? Glob. Chang. Biol., 13: 2052-2064.

Srakaew, N., K. Chatchavalvanich, S. Kovitvadhi, U. Kovitvadhi and A. Thongpan, 2010. Histological observation on gonad development of the freshwater pearl mussel, Hyriopsis (Limnoscapha) myersiana. Invert. Reprod. Devel., 54(4): 203-211. 


\section{EFFECTS OF DISSOLVED OXYGEN CONCENTRATIONS ON GROWTH, SURVIVAL AND GONADAL DEVELOPMENT OF LAMELLIDENS MARGINALIS}

Stevens, A.M. and C.J. Gobler, 2018. Interactive effects of acidification, hypoxia, and thermal stress on growth, respiration, and survival of four North Atlantic bivalves. Mar. Ecol. Prog. Ser., 604: 143161.

Sumon, K.A., M.F. Yesmin, P.J. Van den Brink, R. H. Bosma, E.T.H. M Peeters and H. Rashid, 2019. Effects of long-term chlorpyrifos exposure on mortality and reproductive tissues of Banded Gourami (Trichogaster fasciata). J. Environ. Sci. Health B. 54 (7): 549-559.

Talmage, S.C.and C.J. Gobler, 2010. Effects of past, present, and future ocean carbon dioxide concentrations on the growth and survival of larval shellfish. Proc. Natl. Acad. Sci. USA, 107: $17246-17251$.

Tang, B. and H.U. Riisgård, 2018. Relationship between oxygen concentration, respiration and filtration rate in blue mussel Mytilus edulis. J. Oceanol. Limnol., 36(2): 395-404.

Waldbusser, G.G., E. L. Brunner, B.A. Haley, B. Hales, C.J. Langdon and F.G. Prahl, 2013. A developmental and energetic basis linking larval oyster shell formation to acidification sensitivity. Geophys.. Res. Lett., 40: 2171-2176.

Wall, C.C., B.J. Peterson and C.J. Gobler, 2008. Facilitation of seagrass Zostera marina productivity by suspension-feeding bivalves. Mar. Ecol. Prog. Ser., 357: 165-174.

(Manuscript received: 18 April 2021) 